\title{
THE EDUCATION LEADERSHIP IN GLOBAL PERSPECTIVE
}

\author{
Yuswo Adifatoni \\ Kutai Kartanegara University, Indonesia \\ adyfathoni@yahoo.co.id
}

\begin{abstract}
This article looks closely on the deep identification of the global theoretical perspectives in educational leadership and Javanese culture leadership as the main sources of Indonesian leadership models. The discussion focuses on the definition of leadership, various leadership styles, leadership approaches, concept of power, as well as the issue of gender and leadership. At the end of discussion will give understanding on the quality of school principal leadership not only theoretical ideas but also the practical one for the Indonesian school.
\end{abstract}

Keywords: Education, Leadership, Global Perspective

\section{THE DEFINITION OF LEADERSHIP}

Every educational expert has different perspectives on how to define the term of 'leadership'. Therefore, it is possibly a confusing concept for some as each definition seems to emphasize on one aspect of leadership more than other. The term of leadership, of course, has been broadly defined based on the contexts of the experts viewed. Cheng (1996) clearly argues that whichever view of leadership is discussed, there is general agreement that leadership is the process of influencing others' behavior to reach goal development and achievement.

Furthermore, Dean (1987) identifies leadership as direction, sharing school goals, and persuading other school staff to work towards them. Meanwhile, Hersey and Blanchard cited in Nathan (1996) view leadership as the ability to influence the activities of an individual, group and team of work to take them in a desired direction in a given situation. Furthermore, leadership tends to focus on the identification and articulation of corporate values and the implementation of an organization's vision for the future through strategic planning.

While, Dunford et al. (2000) says that leadership is a very personal thing that calls on all of the individuals resources of wisdom, experience, patience, and compassion. It requires flexibility, confidence and risk taking. It can be lonely and yet the rewards can be exhilarating. Bass (1990) defines leadership into various perspectives as follows;

Script Journal Volume 1, Issue 1, April 2016 || ISSN 2477-1880 || E-ISSN 2502-6623

http://jurnal.fkip-uwgm.ac.id/index.php/Script 
1. The leadership is nucleus of a tendency and social movement. By virtue of his/her leader position, he/she performs as a primary agent for judgment of the group structure, atmosphere, goals, ideology and activities.

2. Leadership is viewed as a personality and its effect in which a leader possesses the greatest number of variable traits of personality and character. By these personal qualities, a leader will be able to carry psychological stimuli to others to accomplish a given task.

3. Leadership a s the art of inducing compliance. It is the ability to impress the will of the follower and to induce obedience, respect, loyalty, and co-operation, so the followers will behave in desired manner.

4. Leadership as the exercise of influence. The leader creates interactive communication and demonstrates interpersonal influence to achieve a specified goal.

5. Leadership as an act or behavior. The leadership is the behaviour of an individual by which he/she directs group activities. The leader's involvement in group activities is significant.

6. Leadership as a form of persuasion. Leadership is the powerful activity of persuading people to co-operate to achieve determined objectives.

7. Leadrship as a power relation. The leader has right to establish behavior patterns for others. The interpersonal power might be provided from referent, expert, reward-based, coercive and legitimate power.

Moreover, in the Indonesian perspectives there should be a national trend of leadership in 1980s and 1990s that was 'Pancasila Leeadership' Atmodiwiryo (2000). It means a leadership that possesses the ideology of 'Eka Prasetya Pancakarsa'. This is defined as single determined willingness to execute the five principles of Pancasila, in leading the organization or institution to actualize the institutional goals. Pancasila is derived from Javanese Language that consists of two words, 'Ponco (five) and silo (verses or principles)'. So Pancasila is meant as five verses or principles. The five principles are as follows;

(1) Belief in the one Supreme God,

(2) Just and civilized humanity,

(3) The unity of Indonesia,

(4) Democracy guided by inner wisdom in unanimity arising out of deliberation among representatives,

(5) Social Justice for all the people of Indonesia

Script Journal Volume 1, Issue 1, April 2016 || ISSN 2477-1880 || E-ISSN 2502-6623

http://jurnal.fkip-uwgm.ac.id/index.php/Script 
Pancasila leadership means a leader of institution or organization should be able to implement the values of Pancasila itself as a way of life which appreciates democracy and individual empowerment. In daily school life, for instance, school leader has to consider and listen to his/her staff's voices rather than his/her own opinion in school decision making. The majority voices should be considered as the unanimous decision. Moreover, as part of socialization of Pancasila, it has been entitled as a curriculum not only in formal education from elementary school to university but also in non-formal education. A pancasila simulation is also carried out for the youth society and uneducated people in the villages

\section{THE LEADERSHIP STYLE}

In terms of school management, every headmaster has different principles in managing the schools. It might be a combination of two or more styles, but of course the most dominant belongs to them as their characteristics. Basically, the way the head manages the school is extremely influenced by the social culture around him/her, not only in his/her school but also where he/she lives in (MacBeath, 1999). In Indonesia, for example, the national leadership has been influenced by Javanese culture. Even Javanese culture is no identical to Indonesian culture, but seen from the composition of inhabitants, almost $75 \%$ live in Java. Historically, Javanese culture is the oldest culture in Indonesia. Lambord cited in Tilaar (2001) states that Java is a cross culture of variety of the world culture. Not surprisingly, the values of Javanese culture have strong influence on the concept of national leadership. Culturally, a good school leader is characterized with 'rame ing gawe' (hard working) and 'sepi in pamre' (hard working without wishing any praises or rewards' or 'talkless do more' Sadler (1997) focuses the leadership style on the following perspectives;

\section{The autocratic}

The leader takes the decisions and announces them.

\section{The persuasive}

The leader at this point on the scale also takes all the decisions for the group without discussion or consultation but believes the people will better motivated if they are persuaded that the decisions are good ones.

\section{The consultative}

The significant feature of consultative leadership is that the leader confers with the group members before taking decision and in fact, considers their advice and their feelings when framing decisions.

Script Journal Volume 1, Issue 1, April 2016 || ISSN 2477-1880 || E-ISSN 2502-6623 


\section{The democratic}

Using this style the leader would characteristically lay the problem before his or her subordinates and invite discussion.

According to Blasé \& Anderson (1995), leadership style can be categorized into; open leadership, closed leadership, and open and closed leadership.

\section{Open Leadership}

This leadership style tends to provide a willingness to share power and delegate responsibilities to the staff. This style contributes honesty, communication, participation and collegiality to teachers and other school staffs. It doesn't mean that they must be totally powerful and autonomous in doing their tasks, but the rules are the basic reference in doing the task. Interestingly, this style leads the staffs to be empowered in doing job, as the school principal who exercises this style willingly accommodates his/her roles to the teachers' and school staffs' competences and commitment. So that when teachers and other school staffs lack of competence but have high commitment, the school principal enthusiastically monitor, control, supervise, and motivate the activities in the daily school life. Conversely, when the teachers have high competence along with high commitment as well, the principal won't be reluctant to delegate his/her responsibilities to them without any suspicion. So they will be more empowered to be involved in school day to day decision making.

\section{Closed Leadership}

It is the opposite of open leadership style. It tends to be less accessible, less supportive, more defensive, more egocentric and more insecure than the open one Blasé \& Anderson (1995). The most dominant characteristic, at school life, of this style is where the school principal usually has an unwillingness to share power or authority, delegation, job description to the school teachers and staffs, particularly when it is financially budgeted. Therefore, this type of leadership leads to the failure on the school management, such as in term of lack of job distribution, stagnant staff creativity, low staff motivation, poor honesty, slow staff professional development and high staff conflict.

\section{Closed and Open Leadership}

This type of leadership is a combination of two previous leadership styles that tends to exercise power based on the degree of closeness and openness in the managerial process. A headteacher who usually possesses this leadership style will try to accumulate the quality of

Script Journal Volume 1, Issue 1, April 2016 || ISSN 2477-1880 || E-ISSN 2502-6623

http://jurnal.fkip-uwgm.ac.id/index.php/Script 
closeness and openness in balance as reflection of his/her power and authority to influence the school teacher and staff at the school environment.

\section{THE LEADERSHIP APPROACH}

How every school principal obtains managerial initiatives to distribute his/her responsibility to the school teacher and staff is really very personal. In this case, Blasé \& Anderson (1995) categorize within different perspectives. Those categories are as follow;

\section{Transactional Leadership}

Blasé \& Anderson (1995) illustrate that this leadership approach provides the degrees of managerial negotiation between a leader and the follower in distributing responsibility in order to get a responsible agreement of delegated job. Bargaining is seen as a key initiative in job delegation. In Indonesian school level, this type of leadership is usually characterized by having routine school teacher and staff meeting to discuss and assign the school job to accomplish particular school targets. The principals usually give something to the school staff in order they get something in return. This type of principal relies heavily on contractual conditions of employment, disciplinary codes, and reward structure. It seems that it leads to creating a school environment that remains essentially static and supportive of the status quo.

\section{Transformative Leadership}

In this level, Blasé \& Anderson (1995) stress the idea on a relationship oriented towards fundamental change in terms of the relevant awareness between both the leader and the followers. At school level, it is situated where the school principal employs equal opportunities among school teachers in decision making and job distribution. Basically, this type of leadership is largely with goals equity and justice within school and other educational institutions.

\section{THE CONCEPT OF POWER}

The issue of power is really sensitive to all individuals in an organization and schools are no exception to this. As a teacher, we can find ourselves in situations where we feel powerful or empowered and other occasions, relatively powerless. When the term of power is coming into our mind, it will often bring a perception of uneasiness about the idea of having power, and exercising power - images of manipulation, deviousness, coercion, dependency and sanction, may come to our mind.

Script Journal Volume 1, Issue 1, April 2016 || ISSN 2477-1880 || E-ISSN 2502-6623

http://jurnal.fkip-uwgm.ac.id/index.php/Script 
The definition of power are numerous and often confusing because of different theoretical approaches used. Some focus on social structure, some on groups, and others on individuals. The most common way of understanding power in work organizations, particularly at school, is to define it as the ability of teacher A to compel or to influence teacher B to act a certain way, even if teacher B doesn't wish to do so. Teacher A is securing the compliance of B because is responding to some power A possesses. The ability of an individual to influence others is understood to be based on four sources of power. Conceptually, these four sources are usually described as Hoyle's (1986) ideas;

\section{Structural}

means that the legitimate power is a property of person, gained through a structural position in the office. A headteacher has the right to make decisions at school as formal organization. In Indonesia, for example, every school principal is usually chosen, some are through long process of particular formal test and assigned by a regional office of the National Education Department based on service time local education authority (Dinas Pendidikan Kabupaten/Kota, in Indonesian). Officially, based on the rule a teacher can join a test or be assigned as a principal candidate when he/she has been 8 years in service. But in the autonomy era, the local government with its high power is able to assign the principal more based on the level of closeness of the teacher and the policy maker in the local government. This autonomy system is able to grow the nepotism and collusion in the regional office. As a result some teachers, who are very ambitious to be a school principal, will ask their relatives, colleagues or somebody else (regional officials) who has a strategic and powerful position to determine and assign the principal. In turn they will usually earn millions of rupiahs from those teachers for such position as a part of legal bribe or gift. It is, of course, affect their dedication in running the school. To get their money back through corruption and manipulation is prospective, strategic, effective ways and avoidable for the principal. Republika (2002) says that the students of SMKN Sumenep protested the principal for his corruption and manipulation on the school finance. They asked the principal to pay the school money back and the local government should quit the principal soon. This type of principal often builds and keeps nice relation with the superordinates to cover his immoral behavior. Nowadays, the bad thing is that corruption and manipulation becomes the best trend in Indonesia even the KPK (corruption commission) has been working hard to clean Indonesian government from

Script Journal Volume 1, Issue 1, April 2016 || ISSN 2477-1880 || E-ISSN 2502-6623 
these by giving various hard sentences to the deers. Hoogvelt in Harber \& Davies (1997) highlights that the customary exchange of gifts was often a normal and integrated part of social behavior but with the change to a modern bureaucracy 'legitimate gifts' becomes 'diguise bribes' and expected by officials before a service will be performed. Disappointingly, the need for extra money on the official's behalf is equally understandable.

\section{Personality,}

in which power is a reflection of personal characteristics of the person. It is often seen as a natural consequence regarding to the quality of an individual's moral behavior, knowledge, religion, capability or social status. Charisma can be taken as an example.

\section{Expertise}

refers to the function of specialized knowledge or skills or access to information. Because of particular professionalism, a person is awarded a power spontaneously.

\section{Opportunity}

means the power that is gained the hierarchical opportunity through ranking system or meritocracy system for essential organizational tasks. Teacher A is being powerful to teacher B and C because of particular tasks he/she carried out in the organization.

From those four sources of power and its explanation, it can be categorized which one is the most difficult and easy to be owned by every single person in the real managerial situation. Moreover, looking at the way how to exercise the power is extremely important. Some say that looking for particular position to get power for personal interest is more urgent than exercising the power on the right track. It is thought that the followers will always obey the instructions without any interruption. This thought tends to be authoritarian and dictatorism model of leadership that had been introduced since in the colonialism era. The power relation can be divided in the following terms;

\section{Power Over}

It is a concept where the leaders attain the institutional goals through their tight control of resources, persuasiveness, and hierarchical post over follower. Essentially, the domination of power often belongs to the school principal who structurally plays a role as a super-ordinate. As a result, the principal is the most powerful person in school life. A consequence of this is possibly an authoritarian situation happens in the day to day school life. As far as I am concerned in the situation, it is common in Indonesia that the principal

Script Journal Volume 1, Issue 1, April 2016 || ISSN 2477-1880 || E-ISSN 2502-6623

http://jurnal.fkip-uwgm.ac.id/index.php/Script 
often exercises his/her power over teachers and school staffs in achieving the school objectives. The process of policy making is dominantly much more a top down procedure rather than a bottom up one. Consequently, teachers and other school staffs have no opportunity to be actively involved in school decision making, even they might be invited they are usually under pressure of the principal to rubber stamp the decisions made.

\section{Power Through}

The concept is when the power exercising is going through motivation and mobilization of groups or individual persons and deals with achieving organization goals. It is commonly viewed as the idea of facilitative approaches in which the principal is not reluctant to share a sense of belonging through teachers and other school staffs toward the school targets.

\section{Power With}

Using this model of power, the school manager's collaboration with teachers and other school staffs will be shifted depending on the issues. The headteacher places himself/herself in the middle position when particular issues need this step. The most important thing is a sense of collaborating between top-position and lower position as this refers to the concept of democracy. Empowering teachers and school staff is a part of this issue, because it sustains collaborative and participatory action between the head and the staff. Empowerment makes teachers and staff innovative, creative, and productive in the school life. In turn it will result on the school effectiveness. When innovation, creativeness, and productiveness belong to teachers and staff, it will enable them to educate the students to be more innovative, creative, and productive in learning. This is the way how to build the character of the students. It means that good behavior, attitude, moral intelligences are built by the innovative, creative, productive, skillful, open minded and charismatic teachers. It can be clearly seen from the explanation of Kirkpatrick (2001);

"Empowering teacher means recognizing that good schools have multiple leaders. Designated leadership positions are held by individuals who are active, committed, and frequently charismatic. But these good schools are also distinguishable because they spawn $\mathrm{co}=$ operative work groups and individuals who are leaders by idea and example". 


\section{THE ISSUE OF GENDER AND LEADERSHIP}

Are male and female different in leadership styles? Culturally the Indonesian people believe that they have different perspectives in leadership style. The most traditional Nahdiyin (Nahdlotul Ulama Moeslem), for example, admit that female is bent to be a leader in every level of organaisation, particularly to be a president. In contrast, Muhammadiyah moeslem let female to be a leader of every level organization, not except a president. The traditional reason why they reject female being a leader is the female role only managing the house works at home no more. But Bass (1990) in Sadler (1997) is very sure that once women have attained leadership positions they behave in very similar ways to men in similar position. Women were seen to use a more democratic, participative approach, compared with a more autocratic, directive style used by men.

The change has been happening in Indonesia since the reformation era. Many women have shown their achievement in leading formal and informal organization. Many of them are the leaders of national parties and government institutions. In educational institutions, so many school principals and university rectors are women. Surprisingly, they are not only skillful in managerial issues but also able to bring the institutions and organization to the top achievement. It means that the women have same ability as men when they are assigned on particular top positions.

\section{THE ROLE OF THE QUALITY OF HEAD LEADERSHIP}

Leadership is one of significant factors in school improvement and effectiveness. However, the quality of school principal leadership is often seen as a key aspect which stimulates the process of reaching school achievement. Sergiovanni cited in Day (1999) argues that leading in a school just like leading in the classroom needs to use both the head and the heart. It requires intelligences, charisma, good deed, good moral and open minded thoughts. As part of succeeding the Indonesian National program of character building, all Indonesia school principals should be aware that they are character builders at school level. Lambord cited in Tilaar (2001) state that Java is a cross culture of variety of the world culture. Not surprisingly, the values of Javanese culture have strong influence on the concept of national leadership launched by Ki Hajar Dewantoro as follows;

\section{Ing Ngarso Sung Tulodo}

means the ability to behave well, polite, friendly, and honest in front of the staff. So he / she is able to be the character builder for the school staff and teachers.

Script Journal Volume 1, Issue 1, April 2016 || ISSN 2477-1880 || E-ISSN 2502-6623 


\section{Ing madyo Mangung Karso}

means the ability to mobilize, facilitate and work the staff cooperatively when in the midle.

\section{Tutwuri Handayani}

means the ability to encourage, controll, and monitor when in behind.

These three concepts of Javanese leadership make the leaders of school are totally different with other formal institutions. Ki Hajar Dewantara's concept put the cultural values as the main characteristics of educational institution leaders as the agent change as well as the character builder. School is the place where morality, norms, attitudes, politeness and friendship are mainly built. As it is stated before that culturally, a good Indonesian school leader is characterized not only with the three Ki Hajar Dewantara's leadership but also with 'rame ing gawe' (hard working) and 'sepi in pamre' (hard working without wishing any praises or rewards' or 'talkless do more'. While Sadler (1997) concentrates the leadership qualities of an effective leader on; The ability to build effective teams, The ability to listen, The capability to make decisions on his own, The ability to retain good people, The ability to surround himself with good people. Moreover, Sadler (1997) argues that charismatic leadership has characteristics as follows; A person with extraordinary gift (bakat luar biasa), A crisis (Tanggap), A radical solution to the crisis (solusi tuntas), Followers attracted to the exceptional person believing that they are linked through him to transcendental powers, Validation of person's gifts and transcendence in repeated experiences of success

\section{CONCLUSION}

Finally it can be concluded that conceptually there many various leadership styles are possibly chosen by every individual Indonesian school leaders in driving the school to gain the school vision and mission. They also can combine two or more model of leadership style to make the managerial school life more effective and efficient. But the unforgettable thing is that school as an educational institution should place on the right track as the agent of change as well as the character builder. Improving the quality of education is the only way, as a consequence that education is as the proper effort to elevate the intellectual life of the nation in accordance with the Preamble of the 1945 constitution as the principle of nation. It is the responsibility of Indonesia Government and the entire nation to intellectualize every citizen. Article 31 stipulates that "(1) every single citizen shall have the right to obtain an education, and (2) the government shall establish and conduct a national education system which shall

Script Journal Volume 1, Issue 1, April 2016 || ISSN 2477-1880 || E-ISSN 2502-6623

http://jurnal.fkip-uwgm.ac.id/index.php/Script 
be regulated by statute". To actualize the Preamble of the 1945 constitution, the Indonesian leadership which focus on Ki Hajar Dewantara's leadership principles; 'Ing Ngarso Sung Tulodo, Ing madyo Mangun Karso, and Tutwuri handayani is the most prospective leadership for Indonesian school. Because it is part of the Indonesian culture.

\section{BIBLIOGRAPHY}

Atmodiwiryo, S. (2000). Manajemen Pendidikan Indonesia. Jakarta: Ardadizya Jaya Ltd.

Bass, B. . (1990). Bass and Stogdill's Hand book of Leadership: Theory, Research, and Managerial Application. New York: The Free Press.

Blasé, J., \& Anderson, G. (1995). The Micropolitics of Educational Leadership. London: Cassell.

Cheng, Y. C. (1996). School Effectiveness and School Based Management: A Mecahanism For Development. London: Falmer Press.

Day, C. (1999). Developing Teachers: The Challenges of Lifelong Learning. London: Falmer Press.

Dean, J. (1987). Managing The Primary School. London: Croom Helm Ltd.

Dunford, J., Fawcett, R., \& Bennet, D. (2000). School Leadership. London: Kogan Page Ltd.

Harber, C., \& Davies, L. (1997). School Management and Effectiveness in Developing Countries. London \& New York: Cassell.

Hoyle, E. (1986). The Politics Of School Management. London: Hodder and Stoughton.

Kirkpatrick, G. (2001). Course Handout on Power and Delegation.

MacBeath, J. (1999). Effective School Leadership: Responding to Change. London: Paul Chapman Publishing Ltd.

Nathan, M. (1996). The Headteacher's Survival Guide. London: Kogan Page Ltd.

Republika. (2002, February). Kasek Diduga Korupsi, Siswa Segel Pintu Sekolah. Jakarta.

Sadler, P. (1997). The Fast Track MBA Series: Leadership. London: Kogan Page Ltd.

Tilaar, H. A. . (2001). In Search of New Paradigms In Education Management and Leadership Based on Indigenous Culture: The Indonesia Case. Magelang: Indonesiatera. 